\title{
Synthesis, Characterization and Biological Activity of a Schiff Base Derived from 3-Ethoxy Salicylaldehyde and 2-Amino Benzoic acid and its Transition Metal Complexes
}

\author{
K. Mounika, B. Anupama, J. Pragathi, and C. Gyanakumari* \\ Department of Chemistry, Osmania University, Hyderabad-500 007, India \\ Received 24 April 2010, accepted in final revised form 11 August 2010
}

\begin{abstract}
A new Schiff base, 3-ethoxy salicylidene amino benzoic acid (ETSAN), has been synthesized from 3-ethoxy salicylaldehyde and 2-amino benzoic acid. Metal complexes of the Schiff base were prepared from nitrate/chloride salts of $\mathrm{Ni}(\mathrm{II}), \mathrm{Co}(\mathrm{II}) \mathrm{Cu}(\mathrm{II})$ and $\mathrm{Zn}$ (II) in an alcoholic medium. The complexes were non-electrolytes in dimethyl sulfoxide solvent (DMSO). The chemical structures of the Schiff-base ligand and its metal complexes were confirmed by various spectroscopic studies like IR, UV-VIS, ${ }^{1} \mathrm{H}$ NMR, ${ }^{13} \mathrm{C}$ NMR, ESI-mass spectra, elemental analysis, molar conductance, thermogravimetric studies and magnetic susceptibility measurements. On the basis of elemental and spectral studies, sixcoordinated geometry was assigned to these complexes. In the light of these results, it is suggested that this ligand acts as neutral and tridentate and coordinates to each metal atom by azomethine nitrogen and oxygen atoms of hydroxyl group of the 3-ethoxy salicylaldehyde, besides the hydroxyl group of the carboxyl group of 2-amino benzoic acid. The mass spectral data confirms the monomeric structure of the metal complexes while the TGA studies confirm the presence of water molecules in the complex. The free Schiff base and its complexes have been tested for their antibacterial as well as antifungal activity by using disc diffusion method and the results discussed.
\end{abstract}

Keywords: Schiff base; 3-ethoxy salicylaldehyde; 2-amino benzoic acid; Metal complexes; Antibacterial activity; Antifungal activity.

(C) 2010 JSR Publications. ISSN: 2070-0237 (Print); 2070-0245 (Online). All rights reserved.

DOI: 10.3329 jsr.v2i3.4899 J. Sci. Res. 2 (3), 513-524 (2010)

\section{Introduction}

The field of Schiff base complexes has been fast developing on account of the wide variety of possible structures for the ligands depending upon the aldehydes and amines. Schiff bases are considered as a very important class of organic compounds, which have wide applications in many biological aspects [1]. Transition metal complexes of Schiff

${ }^{*}$ Corresponding author: Prof_c_gyana@yahoo.co.in 
bases are one of the most adaptable and thoroughly studied systems. These complexes have also applications in clinical and analytical and industrial in addition to their important roles in catalysis and organic synthesis [2]. Studies of a new kind of chemotherapeutic Schiff bases are now attracting the attention of biochemists [3, 4]. Schiff base metal complexes can now be considered a widely studied subject due to their industrial and biological applications [5]. Earlier work reported that some drugs showed increased activity when administered as metal complexes rather than as organic compounds [6, 7]. Maihub et al. [8] synthesized Fe(III) and Os(III) complexes with Schiff base derived from unsubstituted salicylaldehyde and 2-amino benzoic acid and characterized them by various methods like IR, NMR, UV etc. [8]. Morad et al. [9] synthesized $\mathrm{Ni}(\mathrm{II})$ complex with salicylaldehyde and 2-amino benzoic acid and characterized it by various methods and also studied its antibacterial activity.

The present aim of the work is to synthesize a Schiff base derived from 3-ethoxy salicylaldehyde and o-amino benzoic acid and to prepare its transition metal complexes, characterize them and study their antibacterial and anti fungal activities.

\section{Experimetal}

\section{Chemicals}

All chemicals used in this work were reagent grade (BDH/ Aldrich), including the metal salts i.e. $\mathrm{Ni}\left(\mathrm{NO}_{3}\right)_{2} \cdot 6 \mathrm{H}_{2} 0, \mathrm{CuCl}_{2} \cdot 2 \mathrm{H}_{2} \mathrm{O}, \mathrm{ZnCl}_{2}, \mathrm{CoCl}_{2} \cdot 6 \mathrm{H}_{2} 0$, Ethanol, 3-ethoxy salicylaldehyde and 2-amino benzoic acid, Chloroform, DMSO, $\mathrm{CaCl}_{2}, \mathrm{NH}_{4} \mathrm{OH}$. Double distilled water was used.

\section{Instruments}

The percentage compositions of $\mathrm{C}, \mathrm{H}$, and $\mathrm{N}$ of complexes were determined by using micro analytical methods on Perkin Elmer 240C (USA) elemental analyzer. Infrared spectra of the ligand and its complexes were carried out by using $\mathrm{KBr}$ pellets in the range (4000-400 $\left.\mathrm{cm}^{-1}\right)$ on Perkin Elmer Infra red model 337. The electronic absorption was carried out by using a Shimadzu UV-1601 using DMSO as solvent. TGA studies were carried on Mettler Toledo Star system in the temperature range of $0-1000{ }^{\circ} \mathrm{C}$. The Mass spectra were recorded by ESI technique on VG AUTOSPEC mass spectrometer instrument. The ${ }^{1} \mathrm{H}$ and ${ }^{13} \mathrm{C}$ NMR spectra were recorded on Varian Gemini Unity Spectrometer by employing TMS as internal standard. Melting points of the ligand and decomposition temperature of complexes were determined on Polmon instrument (model No.MP-96). The Molar conductance measurements were carried out in DMSO $\left(10^{-3} \mathrm{M}\right)$ using Digisun Electronic Digital conductivity meter of model: DI-909 having a dip-type cell calibrated with $\mathrm{KCl}$. The Magnetic susceptibilities of complexes were determined on Gouy balance model 7550 at $23^{\circ} \mathrm{C}$. The diamagnetic corrections were made by Pascal's constant and $\mathrm{Hg}\left[\mathrm{Co}(\mathrm{SCN})_{4}\right]$ was used as a calibrant. 


\section{Biological activity}

The antimicrobial tests were performed by the standard disc diffusion method [10]. The complexes were screened for their antifungal activity against fungi viz. Aspergillus niger and Fusarium oxysporum. These fungal species were isolated from the infected parts of the host plants i.e potato dextrose agar. The cultures of the fungi were purified by single spore isolation technique. A concentration of $1 \mathrm{mg} / \mathrm{ml}$ of each metal complex compound in DMSO solution was prepared for testing against spore germination of each fungus. Filter paper discs of $5 \mathrm{~mm}$ in size, prepared by using Whatman filter paper no. 1 (sterilized in an autoclave) were saturated with $10 \mu \mathrm{l}$ of the metal complex compounds dissolved in DMSO solution or DMSO as negative control. The fungal culture plates were inoculated and incubated at $25 \pm 2^{\circ} \mathrm{C}$ for $48 \mathrm{~h}$. The plates were then observed and the diameters of the inhibition zones (in $\mathrm{mm}$ ) were measured and tabulated.

The antibacterial activity of the complexes was studied against Gram-positive bacteria Staphylococcus aureus (MTCC 96) and Gram-negative bacteria Escherichia coli (MTCC 443). Each of the metal complex compounds dissolved in DMSO at a concentration of 1 $\mathrm{mg} / \mathrm{ml}$ was prepared. Paper discs of Whatman filter paper no. 1 were cut and sterilized in an autoclave. The paper discs were saturated with $10 \mu \mathrm{l}$ of the metal complex compounds dissolved in DMSO solution or DMSO as negative control and were placed aseptically in the Petri dishes containing Nutrient agar media inoculated with the above mentioned two bacteria separately. The petridishes were incubated at $37{ }^{\circ} \mathrm{C}$ and the inhibition zones were recorded after $24 \mathrm{~h}$ of incubation.

\section{Synthesis of Schiff base (ETSAN)}

The Schiff base was prepared by condensation of 3-ethoxy salicylaldehyde (1.66 g; $0.01 \mathrm{~mol})$ with 2-amino benzoic acid $(1.37 \mathrm{~g} ; 0.01 \mathrm{~mol})$ in ethanol $(25 \mathrm{~mL})$ and the mixture was refluxed for $2 \mathrm{hrs}$. The resulting solution was evaporated under vacuum to remove the solvent. The product was collected by filtration, washed several times with ethanol and recrystallized from hot ethanol and dried in a vacuum desiccator. The melting point of the resulting schiff base was found to be $148^{\circ} \mathrm{C}$. The color of the product is red with $95 \%$ yields.

\section{General experimental procedure for the preparation of the metal complexes}

A mixture of the schiff base under investigation $(0.01 \mathrm{~mol})$ in $25 \mathrm{ml}$ ethanol and the same amount of the same solvent of metal salt $(0.01 \mathrm{~mol})\left(\mathrm{MX}_{2}\right.$, where $\mathrm{M}=\mathrm{Ni}$ (II), $\mathrm{Co}$ (II), $\mathrm{Cu}$ (II) and $\mathrm{Zn}(\mathrm{II}) ; \mathrm{X}=\mathrm{Cl} / \mathrm{NO}_{3}$ /acetates ) were refluxed for two hours at $70-80^{\circ} \mathrm{C}$ on water bath . On cooling, colored solid product was collected by filtration and then washed several times with hot ethanol until the washing becomes colorless. The product was dried in air and stored in a desiccator over anhydrous $\mathrm{CaCl}_{2}$ under vacuum .All the metal complexes are colored and stable to air and moisture. 


\section{Results and Discussions}

The condensation of 3-ethoxy salicylaldehyde and 2-amino benzoic acid in ethanol yields a single product according to following reaction:

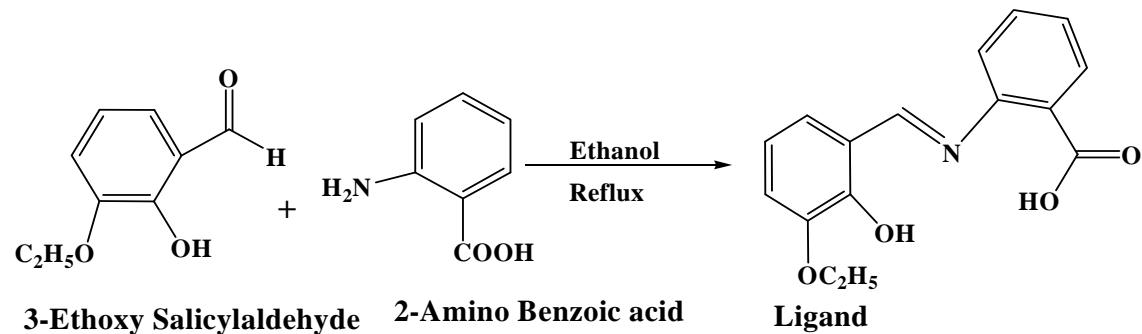

\section{Physical properties}

All the complexes are stable at room temperature and are non-hygroscopic. On heating, they decompose at high temperatures. The complexes are insoluble in water but are soluble in DMSO. The analytical data and physical properties of the ligand and complexes are summarized in Table 1.

Table 1. Analytical data and physical properties of the ligand and its complexes.

\begin{tabular}{|c|c|c|c|c|c|c|c|c|c|}
\hline \multirow[t]{2}{*}{ Comp. } & \multirow{2}{*}{$\begin{array}{l}\text { Empirical } \\
\text { formula }\end{array}$} & \multirow{2}{*}{$\begin{array}{l}\text { Mol. } \\
\text { wt. }\end{array}$} & \multirow[t]{2}{*}{ Colour } & \multirow{2}{*}{$\begin{array}{l}\text { m.p. } \\
\left({ }^{\circ} \mathrm{C}\right)\end{array}$} & \multirow{2}{*}{$\begin{array}{l}\text { Yield } \\
(\%)\end{array}$} & \multicolumn{3}{|c|}{ Elements found (calc.) } & \multirow{2}{*}{$\begin{array}{l}\Omega \\
\left(\mathrm{Ohm}^{-1}\right. \\
\left.\mathrm{cm}^{2} \mathrm{~mol}^{-1}\right)\end{array}$} \\
\hline & & & & & & $\mathrm{C}$ & $\mathrm{H}$ & $\mathrm{N}$ & \\
\hline Ligand & {$\left[\mathrm{C}_{16} \mathrm{H}_{15} \mathrm{NO}_{4}\right]$} & 285 & Red & 142 & 95 & $\begin{array}{l}67.23 \\
(67.36)\end{array}$ & $\begin{array}{l}5.58 \\
(5.26)\end{array}$ & $\begin{array}{l}5.04 \\
(4.91)\end{array}$ & - \\
\hline $\begin{array}{l}\mathrm{Ni}(\mathrm{II}) \\
\text { complex }\end{array}$ & {$\left[\mathrm{NiC}_{16} \mathrm{H}_{21} \mathrm{NO}_{8}\right]$} & 414 & $\begin{array}{l}\text { Light } \\
\text { green }\end{array}$ & $>300$ & 75 & $\begin{array}{l}46.68 \\
(46.37)\end{array}$ & $\begin{array}{l}5.19 \\
(5.07)\end{array}$ & $\begin{array}{l}3.45 \\
(3.38)\end{array}$ & 5.8 \\
\hline $\begin{array}{l}\mathrm{Co}(\mathrm{II}) \\
\text { complex }\end{array}$ & {$\left[\mathrm{CoC}_{16} \mathrm{H}_{21} \mathrm{NO}_{8}\right]$} & 415 & $\begin{array}{l}\text { Light } \\
\text { orange }\end{array}$ & $>300$ & 63 & $\begin{array}{l}46.85 \\
(46.26)\end{array}$ & $\begin{array}{l}5.31 \\
(5.06)\end{array}$ & $\begin{array}{l}3.49 \\
(3.37)\end{array}$ & 6.7 \\
\hline $\begin{array}{l}\mathrm{Cu}(\mathrm{II}) \\
\text { complex }\end{array}$ & {$\left[\mathrm{CuC}_{16} \mathrm{H}_{21} \mathrm{NO}_{8}\right]$} & 418.5 & $\begin{array}{l}\text { Dark } \\
\text { green }\end{array}$ & 260 & 82 & $\begin{array}{l}46.05 \\
(45.87)\end{array}$ & $\begin{array}{l}5.14 \\
(5.01)\end{array}$ & $\begin{array}{l}3.62 \\
(3.34)\end{array}$ & 10.1 \\
\hline $\begin{array}{l}\mathrm{Zn}(\mathrm{II}) \\
\text { complex }\end{array}$ & {$\left[\mathrm{ZnC}_{16} \mathrm{H}_{21} \mathrm{NO}_{8}\right]$} & 420.5 & $\begin{array}{l}\text { Half } \\
\text { white }\end{array}$ & 220 & 60 & $\begin{array}{l}45.91 \\
(45.65)\end{array}$ & $\begin{array}{l}5.11 \\
(4.99)\end{array}$ & $\begin{array}{l}3.49 \\
(3.32)\end{array}$ & 13.2 \\
\hline
\end{tabular}

Elemental analysis: It is clear from the data that the experimental values shown for each of the compound are in good agreement with the theoretical values calculated for 1:1 
ratio. The composition assigned to the ligand and its complexes may, therefore be formulated as presented in Table 1 .

Molar conductance: The Molar Conductance of metal complexes are measured using $10^{-3} \mathrm{M}$ DMSO solvent, the obtained values (Table1) suggests the presence of a nonelectrolytic nature [11] and that no anions are present outside the coordination sphere.

\section{Thermal analysis}

A representative thermogram of $\mathrm{Ni}$ - complex is given in Fig. 1. It is found from the figure that the heating rates were suitably controlled at $10{ }^{\circ} \mathrm{C} \mathrm{min}-1$ under nitrogen atmosphere and the weight loss was measured from the ambient temperature upto $1000{ }^{\circ} \mathrm{C}$. Thermogram of Ni- complex indicated a total weight loss of $67 \%$ up to $1000^{\circ} \mathrm{C}$, which is observed in three steps, (i) a small weight loss in the range of $40{ }^{\circ} \mathrm{C}-80{ }^{\circ} \mathrm{C}$ which is assigned to loss of lattice water, (ii) maximum weight loss in the range of $390-450{ }^{\circ} \mathrm{C}$ is attributable to the loss of coordinated water (iii) and gradual weight loss in the range of $540-1000{ }^{\circ} \mathrm{C}$ can be assigned to complete decomposition of ligand moiety around the metal ion [12] respectively .Finally the complex is converted into its metal oxide $[13,14]$. The presence of water molecules is further confirmed by the endothermic bands observed in respective DTA curve in the temperature region where TGA curves indicate loss in weight. The DTA curve of the complex showed endothermic peaks at $80{ }^{\circ} \mathrm{C}$, a sharp peak at $430{ }^{\circ} \mathrm{C}$, and $480^{\circ} \mathrm{C}$, and a small exothermic peak at $560{ }^{\circ} \mathrm{C}$ which are attributed to phase transition accompanied by loss of water and decomposition of the complex.

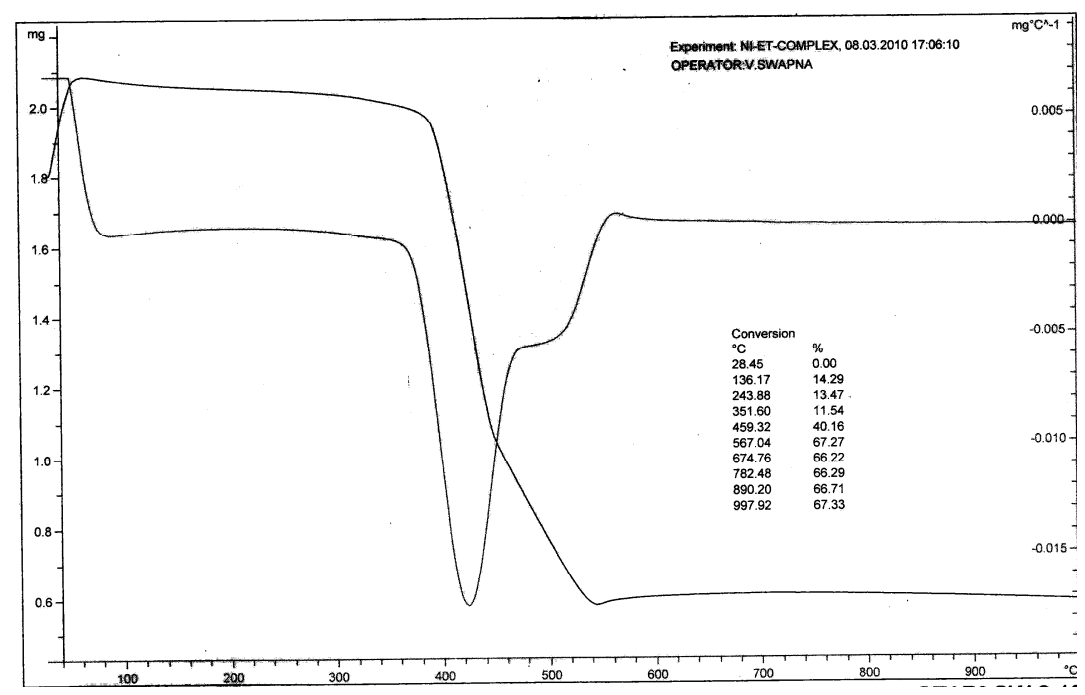

Fig. 1. Thermogram of Ni(II) complex. 


\section{Infrared spectra of the Schiff base and its complexes}

The IR spectra provide valuable information regarding the nature of functional group attached to the metal atom. In order to study the bonding mode of schiff base to the metal complexes, the IR spectrum of the free ligand is compared with the spectra of the complexes. The main IR bands and their assignments are listed in Table 2.

- The IR band assignments of all metal complexes exhibit broad bands in the range of 3354 to $3423 \mathrm{~cm}^{-1}$ indicating the presence of coordinated water molecules [15].

- A band at $1622 \mathrm{~cm}^{-1}$ in free schiff base is due to $\mathrm{vC}=\mathrm{N}$ vibration. The shifting of this group to lower frequency $\left(1592-1556 \mathrm{~cm}^{-1}\right)$ in the metal complexes when compared to free ligand, suggests the coordination of metal ion through nitrogen atom of azomethine group [16]. It is expected that coordination of nitrogen to the metal atom would reduce the electron density in the azomethine link and thus lower the $-\mathrm{HC}=\mathrm{N}$ absorption.

- A band at $1692 \mathrm{~cm}^{-1}$ is assigned to $\mathrm{vC}=\mathrm{O}$ stretching frequency in the spectrum of free schiff base which is also shifted to lower frequency ranging from 1654-1586 $\mathrm{cm}^{-1}$ in all the metal complexes. This indicates the involvement of oxygen atom of hydroxy group of $\mathrm{COOH}$ group in bonding with metal ions [17]

- New bands, which are not present in the spectrum of ligand appeared in the spectra of complexes in the range of $505-562 \mathrm{~cm}-1$, corresponding to $v \mathrm{M}-\mathrm{N}[18,19]$ and $414-436 \mathrm{~cm}^{-1}$ to $v \mathrm{M}-\mathrm{O}$ vibrations respectively. The appearance of $v \mathrm{M}-\mathrm{N}$ and $v \mathrm{M}-\mathrm{O}$ vibrations support the involvement of $\mathrm{N}$ and $\mathrm{O}$ atoms in complexation with metal ions under investigation [20].

- The $v \mathrm{C}-\mathrm{O}$ (Phenolic) stretching frequency of ligand is seen at $1380 \mathrm{~cm}^{-1}$ which gets shifted to a lower frequency region in the complexes in the range of 1372$1326 \mathrm{~cm}^{-1}$, and this is indicative of bonding through phenolic oxygen [21].

- Therefore the IR spectral data indicate that the coordination sites of the metal ion are $-\mathrm{C}=\mathrm{N},-\mathrm{C}-\mathrm{O}$ and $\mathrm{Ar}-\mathrm{O}$.

Table 2. Infrared spectra of the schiff base and its complexes in $\mathrm{cm}^{-1}$.

\begin{tabular}{lllllcc}
\hline Compound & $v \mathrm{OH} / \mathrm{H}_{2} \mathrm{O}$ & $v \mathrm{C}-\mathrm{O}$ & $v \mathrm{C}=\mathrm{O}$ & $v \mathrm{C}=\mathrm{N}$ & $v \mathrm{M}-\mathrm{N}$ & $v \mathrm{M}-\mathrm{O}$ \\
\hline Ligand[ETSAN] & 3437 & 1380 & 1692 & 1622 & - & - \\
$\mathrm{Ni}(\mathrm{II})$ complex & 3429 & 1372 & 1586 & 1556 & 520 & 425 \\
$\mathrm{Co}(\mathrm{II})$ complex & 3354 & 1363 & 1654 & 1588 & 562 & 418 \\
$\mathrm{Cu}(\mathrm{II})$ complex & 3430 & 1327 & 1614 & 1592 & 555 & 414 \\
$\mathrm{Zn}(\mathrm{II})$ complex & 3423 & 1326 & 1614 & 1591 & 505 & 436 \\
\hline
\end{tabular}




\section{Magnetic moments and electronic spectral data}

The electronic absorption spectra of metal complexes were recorded in DMSO in the range of 200-1000 $\mathrm{nm}$ and are listed in table 3. The electronic spectrum of free schiff base shows three bands at $237 \mathrm{~nm}\left(42194 \mathrm{~cm}^{-1}\right), 270 \mathrm{~nm}\left(37037 \mathrm{~cm}^{-1}\right)$ and $335 \mathrm{~nm}(29850 \mathrm{~cm}$ $\left.{ }^{-1}\right)$ suggesting the presence of $\pi-\pi *$ transition [22]. The electronic spectrum of $\mathrm{Ni}(\mathrm{II})$ complex showed three bands at $16077 \mathrm{~cm}^{-1}, 26178 \mathrm{~cm}^{-1}$ and $32467-37735 \mathrm{~cm}^{-1}$ corresponding to the transitions $\quad{ }^{3} \mathrm{~A}_{2 \mathrm{~g}}(\mathrm{~F}) \rightarrow{ }^{3} \mathrm{~T}_{2 \mathrm{~g}}\left(v_{1}\right),{ }^{3} \mathrm{~A}_{2 \mathrm{~g}}(\mathrm{~F}) \rightarrow{ }^{3} \mathrm{~T}_{1 \mathrm{~g}}(\mathrm{~F}) \quad\left(\mathrm{v}_{2}\right) \quad$ and ${ }^{3} \mathrm{~A}_{2 \mathrm{~g}}(\mathrm{~F}) \rightarrow{ }^{3} \mathrm{~T}_{1 \mathrm{~g}}(\mathrm{P})\left(\mathrm{v}_{3}\right)$. The magnetic moment of Ni-complex was seen at 3.32 B.M within the range of 2.5-3.5 B.M for octahedral Ni(II)complexes[23,24]. The electronic spectrum of Co(II)-complex shows bands at $16286 \mathrm{~cm}^{-1}, 27027 \mathrm{~cm}^{-1}$ and $32051 \mathrm{~cm}^{-1}$ corresponding to the transitions ${ }^{4} \mathrm{~T}_{1 \mathrm{~g}}(\mathrm{~F}) \rightarrow{ }^{4} \mathrm{~T}_{2 \mathrm{~g}}(\mathrm{~F})\left(\mathrm{v}_{1}\right),{ }^{4} \mathrm{~T}_{1 \mathrm{~g}}(\mathrm{~F}) \rightarrow{ }^{4} \mathrm{~A}_{2 \mathrm{~g}}(\mathrm{~F})\left(v_{1}\right)$ and ${ }^{4} \mathrm{~T}_{1 \mathrm{~g}}(\mathrm{~F}) \rightarrow{ }^{4} \mathrm{~T}_{1 \mathrm{~g}}(\mathrm{P})$ $\left(v_{3}\right)$. The magnetic moment of Co(II) complex was seen at 5.01 B.M with in the expected range of 4.7-5.2B.M $[25,26]$ for octahedral geometry. The electronic spectrum of $\mathrm{Cu}(\mathrm{II})$ complex display three prominent bands. A low intensity band at $16583 \mathrm{~cm}^{-1}$ is assignable to ${ }^{2} \mathrm{~T}_{2 \mathrm{~g}} \leftarrow{ }^{2} \mathrm{E}_{\mathrm{g}}$ transition. Another high intensity band in the region $24,096-32258 \mathrm{~cm}^{-1}$ is due to symmetry forbidden ligand $\rightarrow$ metal charge transfer and sharp bands observed at $38461 \mathrm{~cm}^{-1}$ which is due to ligand bands. The magnetic moment of $\mathrm{Cu}$ (II) complex was seen at 1.61 B.M. corresponding to one unpaired electron with a slight orbital contribution to the spin-only-value and the absence of spin-spin interactions. On the basis of electronic spectra and magnetic susceptibility measurements, a distorted octahedral geometry around $\mathrm{Cu}(\mathrm{II})$ is suggested. The $\mathrm{Zn}$ (II) complex shows no $\mathrm{d}-\mathrm{d}$ bands as is expected for a $\mathrm{d}^{10}$ system and was found to be diamagnetic in nature. On the basis of analytical, conductance and spectral data, $\mathrm{Zn}$ (II) complex was assigned an octahedral geometry.

Table 3. Magnetic moments and electronic spectral data for the complexes.

\begin{tabular}{ccc}
\hline \multicolumn{1}{c}{ Complex } & UV-Vis bands cm & \\
\hline Ligand[ETSAN] & $29850 ; 37037$ & $\mu_{\text {eff }}$ B.M \\
Ni(II) complex & $16077 ; 26178 ; 32467 ; 37735$ & - \\
Co(II) complex & $16286 ; 27027 ; 32051 ; 42016$ & 5.01 \\
Cu(II) complex & $16583 ; 24096 ; 32258 ; 38461$ & 1.61 \\
Zn(II) complex & - & dia \\
\hline
\end{tabular}

\section{Mass Spectra}

The ESI mass spectra of the ligand and its metal complexes recorded at room temperature are used to compare their stoichiometric composition and are listed in Table 4.

- The Ligand [L] shows a molecular ion peak at $\mathrm{m} / \mathrm{z} 286$, which corresponds to $[\mathrm{L}+\mathrm{H}]$ peak as the calculated $\mathrm{m} / \mathrm{z}$ being 285 . 
- The mass spectra of $\mathrm{Ni}$ (II) complex shows a molecular ion peak at $\mathrm{m} / \mathrm{z}=414$ and $\mathrm{Co}$ (II) complex shows a peak at $\mathrm{m} / \mathrm{z}=415$ which corresponds to molecular weight of the respective compounds while that of $\mathrm{Cu}$ (II) complex shows $\mathrm{m} / \mathrm{z}=420$ and $\mathrm{Zn}$ (II) complex at $\mathrm{m} / \mathrm{z}=422.5$ which corresponds to[ $\mathrm{M}+1]$ and $[\mathrm{M}+2]$ peaks respectively. These peaks support to the structure of the complexes and confirm the stoichiometry of metal chelates as ML type.

- The different molecular ion peaks appeared in the mass spectra of complexes (abundance range $2-100 \%$ ) are attributed to the fragmentation of the metal complex molecule obtained from the rupture of different bonds inside the molecule by successive degradation leading to many more important peaks due to formation of various radicals. The spectra of complexes show molecular ion peaks in good agreement with the structure suggested by elemental analysis, spectral and magnetic studies. The spectra of the schiff base and its complexes show characteristic molecular ion peaks at their expected $\mathrm{m} / \mathrm{z}$ values confirming their monomeric forms.

Table 4. Mass spectral data of the ligand and its complexes.

\begin{tabular}{llll}
\hline Compound & Expected $\mathrm{m} / \mathrm{z}$ & Found $\mathrm{m} / \mathrm{z}$ & Peak assigned \\
\hline Ligand[ETSAN] & 285 & 286 & $\mathrm{HL}$ \\
$\mathrm{Ni}(\mathrm{II})$ Complex & 414 & 414 & {$[\mathrm{M}]$} \\
$\mathrm{Co}(\mathrm{II})$ Complex & 415 & 415 & {$[\mathrm{M}]$} \\
$\mathrm{Cu}(\mathrm{II})$ Complex & 418.5 & 420 & {$[\mathrm{M}+1]$} \\
$\mathrm{Zn}(\mathrm{II})$ Complex & 420.5 & 422.5 & {$[\mathrm{M}+2]$} \\
\hline
\end{tabular}

\section{${ }^{1} \mathrm{H}$ and ${ }^{13} \mathrm{C}$-NMR spectra}

The ${ }^{1} \mathrm{H}$ NMR spectrum of the ligand in $\mathrm{CDCl}_{3}$ shows the following signals given in Table 5. The phenyl multiplet is seen at $6.5-7.3 \delta$ and the azomethine proton is seen at $7.6 \delta$ (singlet). The peak at $10.8 \delta$ is attributed to phenolic $\mathrm{OH}$ group present in the ligand. The peak at $1.5 \delta$, which is a triplet, is assigned to $-\mathrm{CH}_{3}$ group of ethoxy substituent on the benzene ring while peak at $4.1 \delta$, which is a quartet, is attributed to $-\mathrm{CH}_{2}$ protons of the ethoxy substituent.

The ${ }^{13} \mathrm{C}$ NMR spectrum of the ligand is recorded in $\mathrm{CDCl}_{3}$ and the spectral data confirms the ${ }^{1} \mathrm{H}$ NMR spectral results. The number of signals in the ${ }^{13} \mathrm{C}-\mathrm{NMR}$ spectrum corresponds to the number of magnetically non-equivalent carbon atoms in the ligand. Azomethine carbon atom is observed at $151.69 \mathrm{ppm}$ and the phenolic carbon is seen at $169.88 \mathrm{ppm}$ while the carboxylic carbon is observed at $194.08 \mathrm{ppm}$. Large chemical shift values for the carbon atoms attached to the azomethine nitrogen, phenolic oxygen and 
carboxylic oxygen suggest coordination of these atoms. Peaks in the region $\delta 110-147$ ppm are due to aromatic carbons. Methyl carbon of ethoxy substituent is seen at 15.13 ppm and methylene carbon is observed at $65.27 \mathrm{ppm}$.

Table 5. ${ }^{1} \mathrm{H}$ NMR Spectral data of the ligand.

\begin{tabular}{clll}
\hline $\begin{array}{c}\text { Chemical shift } \\
(\delta, \mathrm{ppm})\end{array}$ & Mulplicity & $\begin{array}{l}\text { Number of } \\
\text { protons }\end{array}$ & $\begin{array}{l}\text { Functional } \\
\text { group assigned }\end{array}$ \\
\hline $6.5-7.3$ & Multiplet & 7 & $\begin{array}{l}\text { Aromatic } \\
\text { protons }\end{array}$ \\
7.6 & Singlet & 1 & $-\mathrm{HC}=\mathrm{N}$ \\
4.1 & Quartet & 2 & $-\mathrm{OCH}_{2}$ \\
1.5 & Triplet & 3 & $-\mathrm{CH}_{3}$ \\
10.8 & Singlet & 1 & $-\mathrm{OH}$ \\
\hline
\end{tabular}

\section{Antimicrobial activity}

Antibacterial activity: The invitro anti bacterial activity [27] of the ligand and its complexes have been carried out against the gram -ve Escherischia.Coli and gram +ve Staphylococcus aureus using disc diffusion method by taking DMSO as solvent.

A comparative study of the growth inhibition zone values of schiff base and its complexes indicate that metal complexes exhibit higher anti bacterial activity than the free ligand and the same is indicated from the results given in the table 6 . This is probably due the greater lipophilic nature of the complexes. Such increased activity of the metal chelates can be explained on the basis of Overtone's concept and Tweedy's chelation theory [28]. According to Overtone's concept of cell permeability, the lipid membrane that surrounds the cell favors the passage of only lipid soluble materials due to which liposolubility is considered to be an important factor that controls the anti microbial activity. On chelation, the polarity of the metal ion will be reduced to a greater extent due to the overlap of the ligand orbital and partial sharing of positive charge of metal ion with donor groups $[29,30]$ Further, it increases the delocalization of the $\pi$ electrons over the whole chelate ring and enhances the lipophilicity of the complex. This increased lipophilicity enhances the penetration of the complexes into lipid membrane and thus blocks the metal binding sites on enzymes of microorganisms [31]. These metal complexes also disturb the respiration process of the cell and thus block the synthesis of proteins, which restricts further growth of the organism [32]. The variation in the activity of different complexes against different organisms depend either on the impermeability of 
the cells of the microbes or difference in ribosomes of microbial cells. The inhibition zones of antibacterial activity are presented in the Table 6 .

The results indicate that copper complex shows highest activity against E.Coli while cobalt complex shows maximum inhibition zone against S.aureus at $1 \mathrm{mg} / \mathrm{ml}$ concentration.

Table 6. Growth Inhibition Zone of Microbes in $\mathrm{mm}$.

\begin{tabular}{lllll}
\hline Compound & E.coli & S.aureus & A.niger & F. oxysporum \\
\hline Ligand & 5 & 7 & 11 & 15 \\
Ni(II) Complex & 10 & 10 & 13 & 18 \\
Co(II) Complex & 9 & 13 & 12 & 19 \\
Cu(II) Complex & 12 & 11 & 14 & 22 \\
Zn(II) Complex & 11 & 9 & 13 & 20 \\
\hline
\end{tabular}

Antifungal activity: The antifungal activities [33] of the ligand and its metal complexes were tested against seven-day old cultures of Aspergillus niger and Fusarium oxysporum using disc diffusion method. The results show that the metal complexes were more active than the free ligand and can be explained by Overtone's concept and Tweedy's chelation theory. The mode of action of the compounds may involve formation of a hydrogen bond through the azomethine group with the active centers of cell constituents, resulting in an interference with normal cell process [34].

The antifungal activity data (Table 6) indicate that the complexes show an appreciable activity against Aspergillus niger and Fusarium oxysporum at $1 \mathrm{mg} / \mathrm{ml}$ concentration. Ligand has shown a lesser activity as compared to the metal complexes. The experimental results of the compounds are expressed as inhibition zone diameter (in $\mathrm{mm}$ ). Copper complex shows the highest activity (i.e $14 \mathrm{~mm}$ against $A$. niger and $22 \mathrm{~mm}$ against $\mathrm{F}$. oxysporum at the concentration of $1 \mathrm{mg} / \mathrm{ml}$ ) among all the metal complexes. The other complexes obviously show less activity against these fungi than the copper complex.

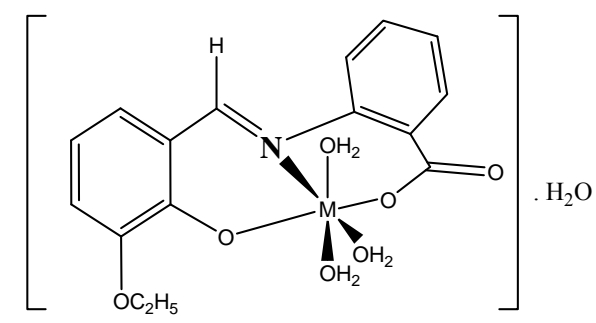

$\mathrm{M}=\mathrm{Ni}(\mathrm{II}), \mathrm{Co}(\mathrm{II}), \mathrm{Cu}(\mathrm{II}), \mathrm{Zn}(\mathrm{II})$

Proposed structure of metal complexes. 


\section{Conclusion}

The ETSAN ligand and its metal complexes of $\mathrm{Ni}(\mathrm{II}), \mathrm{Co}$ (II) $\mathrm{Cu}$ (II) and $\mathrm{Zn}$ (II) have been structurally characterized. The analytical data show that the metal ligand stoichiometry in all these complexes is 1:1. All the complexes are non-electrolytes in DMSO solvent. The spectral data show that the ligand act as neutral and tridentate coordinating through nitrogen atom of the azomethine and oxygen atoms of hydroxyl group of the 3-ethoxy salicylaldehyde beside the hydroxyl group of the carboxyl group of the 2-amino benzoic acid respectively. Based on analytical, molar conductance, magnetic and spectral data, all these complexes are assigned to be in octahedral geometry. Biological studies of these complexes reveal that they show better activity when compared to that of the ligand.

\section{References}

1. B. S. Tovrog, D. J. Kitko, and R. S Dragom, J. Am. Chem. Soc. 98, 5144 (1976). doi:10.1021/ja00433a016

2. H. Sharghi and M. A. Nasseri, Bull. Chem. Soc. (Jpn.) 76, 137 (2003). doi:10.1246/bcsj.76.137

3. Y. K. Choi, K. H. Chjo, S. M. Park, and N. Doddapaneni, J. Electrochem. Soc. 142, 4107 (1995). doi:10.1149/1.2048472

4. B. Katia, L. Simon, R. Anne, C. Gerard, D. Francoise, and M. Bernard, Inorg. Chem. 35, 387 (1996). doi:10.1021/ic950700i

5. Z. M. Zaki, S. S. Haggag, and A. A. Soayed, Spectroscopy Letters 31, 757 (1998). doi:10.1080/00387019808007397

6. E. M. Hodnett and P. D. Mooney, J. Med. Chem. 13, 786 (1970). doi:10.1021/jm00298a065

7. E. M. Hodnett and W. J. Dunn, J. Med. Chem. 15, 339 (1972). doi:10.1021/jm00273a037

8. A. A.Maihub, M. M. El-Ajaily, J. Science Appls. 1 (1), 275 (2006).

9. F. M. Morad, M. M. El-Ajaily, and S. Ben Gweirif, J. Science. Appls. 1 (1),72 (2007).

10. W. L. Drew, A. L. Barry, R. O’Toole, J. C. Sherris, Appl. Environ. Microbiol. 24, 240 (1972).

11. W. G. Geary, Coord. Rev. 7, 81 (1971). doi:10.1016/S0010-8545(00)80009-0

12. G. Bhargavi, B. Sireesha, and Ch. Sarala Devi, Bulletin of Pure and Applied Sciences. 21, 1, (2002).

13. E. S. Freeman and B. J. Carroll, J. Phy. Chem. 62, 394 (1958). doi:10.1021/j150562a003

14. A. P. Mishra and M. Khare, J. Ind. Chem. Soc. 77, 367 (2000).

15. B. Jezowska, J. Lisowski, and P. Chmielewski, Polyhedron 7, 337 (1988). doi:10.1016/S0277-5387(00)80480-5

16. J. M.Sece, M. Quiros, and M. J. G. Garmendia, Polyhedron 19, 1005 (2000). doi:10.1016/S0277-5387(00)00356-9

17. A. M. El-Roudi, Faculty Science, Assiut University 18, 77 (1989).

18. M. Thomas, M. K. M. Nair, and P. K. Radhakrishnan, Synth. React. Inorg. Met Org. Chem. 25, 471 (1995). doi:10.1080/15533179508218235

19. K. Nakamoto, Infrared and Raman Spectra of inorganic and coordination compounds, $3^{\text {rd }}$ Edition (Wile, New York, 1997).

20. A. . Jain, R. Goyal, and D. D. Agarwal, J. Inorganic Nuclear Chem. 43, 2005 (1981).

21. L. Lindoy, W. E. Moody, and D. Taylor, Inorg. Chem. 16, 1962 (1997). doi:10.1021/ic50174a027

22. M. D. Boghaei, S. J. S. Sabounche, and S. Rayati, Synt. Reac. Inorg. Metal-Org. Chem. 30, 1535 (2000). 


\section{Synthesis, Characterization and Biological}

23. O. Kahn, Molecular Magnetism (VCH, Weinheim,Germany, 1993).

24. X. Y. Le, M. L. Tong, J. Inorg. Chem. 18, 1023 (2002).

25. S. A. Patil, V. H. Kulkarni, Polyhedron 3, 21 (1984). doi:10.1016/S0277-5387(00)84706-3

26. S. H. Fetoh, A. E. Eid, A. I. Abo, H. S. El-Kareem, and M. A. Wassel, Synth. React. Inorg. 30 , $513(2000)$.

27. F. Simoncini, R. Rangone, and C. Calanni, Farnance Ed. Prat. 23(10), 559. Chem. Abstr., 69, 109851d (1968).

28. B. G. Tweedy, Phyto Pathology 55, 910 (1964).

29. K. Kralova, K. Kissova, O. Svajlenova, and J. Vanco, Chem. Pap. 58 (5), 361 (2000).

30. J. Parekh, P. Inamdhar, R. Nair, S. Baluja, and S. Chanda, J. Serb. Chem. Soc. 70, 1161 (2005).

31. Y. Vaghasia, R. Nair, M. Soni, S. Baluja, and S. Chanda, J. Serb. Chem. Soc. 69, 991 (2004).

32. N. Raman, Res. J. Chem. Environ. 4, 9 (2005).

33. H. W. Seely and P. J. Van Demark, Microbes in Action, Laboratory of Microbiology, 3rd Ed. (W. H. Freeman and Co. USA, 1981) p. 385.

34. N. Dharamraj, P. Viswanathanmurthi, and K. Natarajan, Trans. Met. Chem. 26, 105 (2001). doi:10.1023/A:1007132408648 